\title{
Ibn Al-Abbâr, un intelectual y político de origen ondense
}

\author{
Vicent Aguilella Felis
}

\section{Introducción}

La profesora de la Universidad Autónoma de Madrid, Dña. Gema Martín Muñoz, ${ }^{1}$ comenta: «Otro viejo problema que hay en este país es que no se considera español la riquísima literatura y pensamiento de Al-Ándalus y no se enseña nada de estos autores». Las lagunas existentes «nos invitan a repensar Al-Ándalus, cuando fue la experiencia civilizacional más larga que hemos tenido. No podemos ignorarla».

Todas las culturas que han habitado en la península Ibérica nos han dejado sus legados. Una de las que más ha aportado ha sido, sin duda alguna, la musulmana, y aún más por nuestra zona y Andalucía. La cultura en el período de Al-Ándalus está considerada como la época de oro del islam: convivieron algunos de los más grandes artistas, científicos, literatos y pensadores de esta cultura. El conocimiento andalusí se fundamenta en el islam suní, seguidor de los preceptos islámicos y respetuoso con la autoridad.

1 Arabista española (1955), profesora visitante en la Univ. de Harvard y colaboradora de La Sorbona, asesora de la presidencia del Gobierno, con Felipe González y J. M. ${ }^{a}$ Aznar. En el 2006 recibió del presidente egipcio la Gran Orden de las Ciencias y de las Artes.

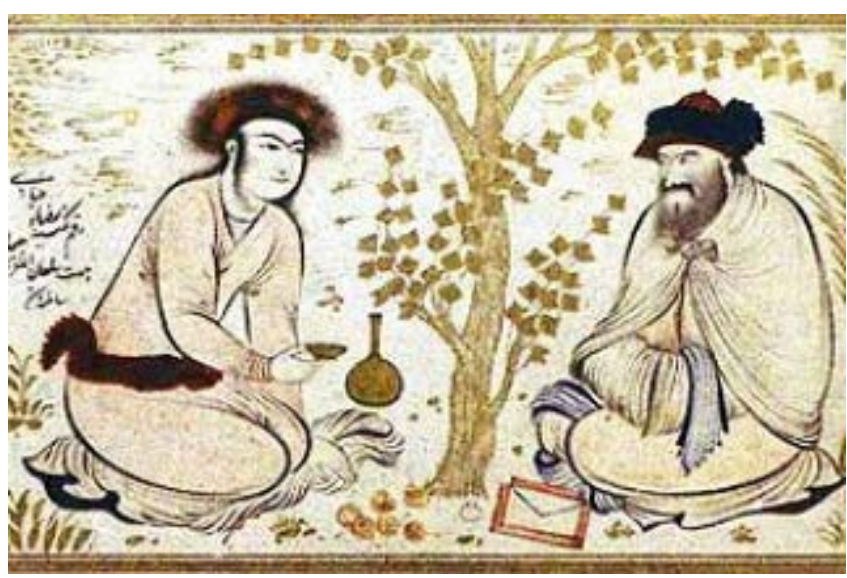

Figura 1

Destacaron en todos los campos: arte (arquitectura, literatura, artesanía...), ciencias (medicina, astrología, matemáticas, física...), educación, gastronomía, filosofía (cultura griega de Aristóteles), tecnología...

Onda, como medina importante durante algunas épocas del período andalusí, tenía una gran influencia en el ambiente cultural, aunque solo quedan algunos testimonios a partir de los siglos XII y XIII.

Según diccionarios bibliográficos de Al-Ándalus, se pueden contar, entre el siglo XII y el primer tercio del XIII, cerca de 201 sabios de Valencia, 105 letrados en Xàtiva, 60 en Dénia, 18 en Onda, 21 
en Llíria, 33 en Alcira y otros muchos en pequeñas poblaciones como Segorbe, Bairén y Cocentaina. ${ }^{2}$

De los personajes originarios de Onda, que hacen su contribución a la cultura musulmana, el más destacado sin duda fue el escritor y político Ibn al-Abbar, que aportó a esta cultura muchas obras, aunque la que contribuyó a dar a conocer más a la sociedad andalusí fue la At-Takmila (at-Takmila fi kitab as-Sila), libro bibliográfico de unos tres mil ciudadanos ilustres de Al-Ándalus, de los siglos VIII-XIII. Es uno de los libros más estudiados de la cultura andalusí, que sirve como complemento de otro libro, la Sila de Ibn Baskuwál, que solo llega hasta el s. XII.

Gracias a la At-Takmila conocemos a grandes personajes vinculados a Onda, aunque solo sea de la última época musulmana (s. XII y XIII). La influencia de estos, tanto política como cultural, sobre todo en Sharq Al-Ándalus, recae en veintitrés personajes, científicos, políticos, viajeros, escritores y otras ramas. Hay dos familias que destacan: los Banu Haut-Allah y los Quda'ins, que se propagaron por todo el Al-Ándalus, pero siempre recordando sus raíces en la medina de Ünda.

Según el profesor Mikel de Epalza: ${ }^{3}$

Ibn Al-Abbâr, escritor y político, es sin ninguna duda el personaje musulmán más importante de las actuales tierras valencianas, de los nueve siglos que vivieron los árabes y musulmanes al País Valencià. Su personalidad no sólo es apreciada como poeta, alfaquí, diplomático y político, sino que aún es mucho más valorada y célebre como historiador, tradicionista y biógrafo. En su vida y trabajos siempre destacó el gran amor que tenía a su tierra Shar-Andalus, sus gentes y sus orígenes.

Muhammad ibn (figura 2) Abdallâh Ibn Abu Bakr Ibn al-Abbâr al Qudâ i, conocido por Ibn al-Abbâr,

2 Lachica Garrido, Margarita (1995). Poetas árabes del País Valenciano. Universidad de Alicante.

3 (1938-2008) Uno de los más importantes arabistas españoles. Obtuvo cuatro licenciaturas, diplomado en enseñanza del árabe y doctor en filosofía y letras (filología semítica, árabe), profesor en las Universidades de Barcelona (1965), Lyon (1968), Túnez (1971), Argel y Orán (1973), ComillasMadrid (1974), Autónoma de Madrid (1976) y Alicante. Tradujo el Corán al catalán.

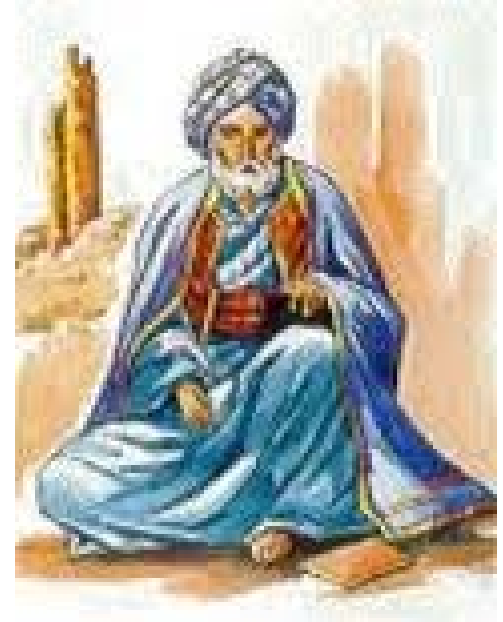

Figura 2

como él mismo escribe en At-Takmila, «mi nacimiento se produce durante la oración de la mañana en uno de los meses de Rabi'u del año de la hiyra $595^{4}$ ». Sería el 1 de marzo de 1199 en Balansiya (Valencia). Muere exiliado en Túnez en 1260.

Sus antepasados de la noble tribu de Quda'i o Quraysh (qurayš), a la que pertenecía Mahoma y la mayoría de califas de origen yemení, se instalaron desde antiguo en Unda. Posteriormente, se expandieron por todo el Al-Ándalus, pero siempre hicieron referencia a sus raíces ondenses. El lugar de origen tenía gran importancia en los musulmanes, ya que reflejaba la pertenencia a un linaje distinguido. Incluso nuestro personaje hace hincapié varias veces en sus escritos que los Quda'is de AlÁndalus son todos originarios de Onda.

Hoy en día, aún existe en el término municipal de esta población una partida agrícola denominada Ben Abar, topónimo del nombre de esta ilustre familia. También a nombre de Ibn al-Abbâr hay una calle en Onda, al igual que en Valencia y otras poblaciones. Al-Abbâr era el laqab o sobrenombre de su antepasado, acaso indicativo de su oficio: fabricante de agujas.

Durante siglos, vivieron explotando la tierra, hasta que sus rentas les permitieron dedicarse al estudio de las ciencias islámicas. A mediados del $\mathrm{s}$. xII, Abd-Allah ibn-Abu-Bakr ibn-Abd-Allah ibnAbdi-r-Rahman decide trasladarse a Valencia para

4 Es el año del calendario islámico. El primer día fue el 16 de julio del año 622 de la era cristiana. 
ampliar sus estudios y saberes religiosos. Hombre culto, poeta e intelectual alfaquí, ${ }^{5}$ pasa a formar parte de la élite cultural de Sharq Al-Ándalus. Su hijo Ibn al-Abbâr recibió de él la mejor educación, le facilitó los maestros ulemas más sabios de AlÁndalus y le llevaba a las tertulias literarias. Fue alumno de Abû l-Rabí b. Sâlim y de Abû l-Jattâb b. W. aÿib al-Qaysi, con quien obtuvo su sólida formación de historiador, que le hizo uno de los más importantes de Al-Ándalus. Es la época de máximo esplendor cultural andalusí, cuando termina de morir Averroes. ${ }^{6}$

Se identifica con los intelectuales y altos funcionarios civiles; los considera el mayor valor de la sociedad islámica y, por eso, dedica la mayor parte de sus obras a estas gentes sabias y religiosas. Distingue entre los señores de la pluma y los señores de la espada y no siente simpatía hacia los militares, a los que responsabiliza de la pérdida de los territorios musulmanes frente a los cristianos.

Según parece, no tuvo hermanos varones, pues no los cita al hablar de su padre en At-Takmila, ni al referir que heredó de él todos sus libros. Tuvo una juventud alegre, cultivando la poesía e iniciando pronto la carrera administrativa. Viajó por todo Al-Ándalus para ampliar sus conocimientos de alfaquí. Encontrándose en Badajoz en 1222, supo de la muerte de su padre el día 22 de abril, por lo que volvió y quedó bajo la tutela de su maestro Abû 1-Rabî b. Sâlim. Entonces entró al servicio del gobernador Abú Zayd, como secretario.

Por esa época, debió unirse por matrimonio a la familia valenciana de Ibn al-Wazîr, linaje culto y religioso, originaria de Paterna. Su suegro, $\mathrm{Mu}-$ hammad B. Hasan, conocido por ibn Al-Batarni, fue cadí de varios distritos; era un hombre religioso y de ciencia, que colaboró con él cuando era secretario y marcharon juntos al destierro en Túnez. Se cree que tuvo tres hijas, pues habla de ellas en

5 La sociedad musulmana se rige por las leyes coránicas y la sunna. El alfaquí es un experto en el fiqh o jurisprudencia islámica, considerado sabio o doctor, máxima autoridad religiosa y judicial. El ulema es especialista en la interpretación del Corán y la sunna.

6 Nacido en Córdoba (1126-1198), filósofo y médico, maestro de astronomía, matemáticas, medicina y leyes islámicas. una casida y en otra de sus niños en general, pero no sabemos si se refiere a hijos varones.

En el exilio, escribe importantes libros y forma parte de la corte de dos califas hafsíes, llegando a ocupar altos cargos como ministro, secretario de firma y jefe de cancillería. Pasa por diversas vicisitudes, desterrado y vuelto a llamar a la corte, en varias ocasiones; finalmente, muere brutalmente alanceado por orden del califa, siendo quemado su cuerpo junto a sus obras.

Se le conocen ocho discípulos, entre ellos a Ibn Sâlih al-Kinâni, de Xàtiva, y Abû l-Muhaymân alHadramî, a al-'Abdarî, historiador; en Túnez, a Abû Isháq b. Abi l-Qâsim al-Tuÿinî y a su hijo Abû 1-Hasan b. 'Ali, que recibió de Ibn Sâlih el Durar al-simt, obra clave del chiismo andalusí.

\section{Ibn-al-Abbâr, el político}

Nuestro personaje llega a tener relevancia política tanto en Sharq Al-Ándalus como durante su destierro en Túnez. El poder musulmán medieval necesitaba escritores que expresasen estéticamente los asuntos políticos y alabaran las glorias del poder. Como ya hemos indicado, tuvo una amplia preparación cultural, lo que le llevó a estar al lado de los poderes árabes de los últimos tiempos de Sharq Al-Ándalus.

A principios del siglo XIII, el poder almohade estaba debilitándose por motivos internos (sequía, poca producción agrícola, impuestos, descontento general de las gentes, etc.) y por el avance de las tropas cristianas, ocasión que aprovechan los an-dalusíes para recuperar su independencia política. El califa almohade Al-Ma’mün se trasladó de Sevilla a Marraquech e Ibn Hüd se alzó contra los almohades reconquistando gran parte de AlÁndalus.

Lo mismo sucedía en nuestra zona: el gobernador almohade Zayd Abu Zayd, al ver la caída del poder de los suyos y ante el malestar general de sus gentes, busca asilo junto a los cristianos. Su secretario era Ibn-Abbâr, cargo de gran importancia tanto social como políticamente. 
En 1229, Abû Yamil b. Zayyân Mardânish ${ }^{7}$ (nacido en Onda, descendiente del Muhaàmma ibn Mardânish, el llamado Rey Lobo), hijo del héroe local que se alzó contra los almorávides, protagoniza el mismo papel contra los almohades. Sale de Onda, de la que era el cadí, camino de la conquista de Valencia.

Zayd Abu Zayd huye con su secretario, primero a la zona de Segorbe, posteriormente a tierras cristianas. Era amigo del noble Blasco de Alagón. Ibnal-Abbâr abandona las tierras valencianas sin sus familiares ni allegados. Esta circunstancia aumenta el dolor del destierro, que lo escribe en sus poesías (Diwan), donde aparece el dolor por la nostalgia de su patria y familia y el espiritual por estar rodeado de cristianos.

Abu Zayd pacta con Jaime I en 1229, en la ciudad de Qalat Al-Ayyud (Calatayud), su ayuda militar y vasallaje, así como la rendición de una serie de castillos imprescindibles para la conquista de Valencia. Siempre junto a él se encontraba Ibn-al-Abbâr. Pasado un tiempo, comprende que es prácticamente nula la esperanza de volver a ocupar el trono valenciano y decide ceder sus derechos de Valencia al rey cristiano, lo que se llevó a cabo en febrero de $1232 .{ }^{8}$ Abu Zayd se convertiría al cristianismo con el nombre de Vicent Bellvis y colaboraría estrechamente en la reconquista del reino. Jaime I le recompensó con diversas propiedades (Ibi, Castalla, Onil y Tibi, entre otras) y sus descendientes se emparentaron con la nobleza cristiana. Su hijo se casó con la hija de Blasco de Alagón, entrando a formar parte de la nobleza aragonesa.

De Ibn Al-Abbâr es de destacar su amor y entrega a su tierra, ya que estuvo siempre vinculado a su defensa, pudiendo huir anteriormente con su familia a África, Granada o a tierras andalusís o cristianas con Abu Zaid, pues tenía notoriedad y fortuna, pero prefirió aferrarse a su patria.

Ante todos estos acontecimientos, Ibn al-Abbâr no puede renunciar a sus principios religiosos y mo-

7 Son una dinastía musulmana de origen muladí (hispanovisigodos convertidos al islam). Familia noble, reina en las taifas de Murcia, Valencia, Lleida y Zaragoza.

8 Garcia Edo, Vicent. Archivo de la Corona. Barcelona. Pergamino 480 de Jaime I.

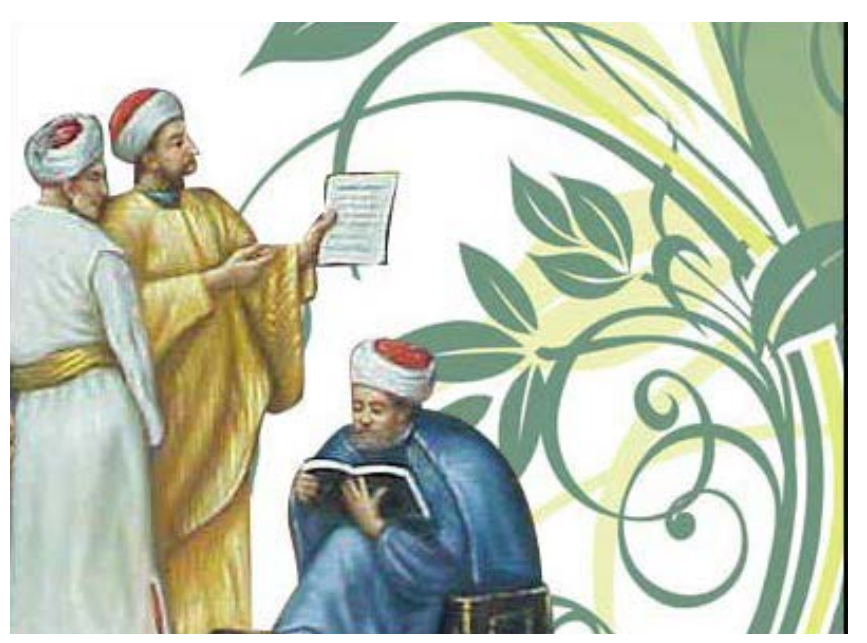

Figura 3

rales y decide abandonarle y volver a Al-Ándalus. Tenía 31 años. No lo hace directamente a Valencia: en agosto de 1229 se encuentra en Guadix, por lo que solo estuvo unos meses en tierras cristianas, de allí se dirige a Xàtiva, siendo asaltado en el viaje. (Diwan 113). ${ }^{9}$

En esta ciudad se encontraba su amigo, el gobernador Abu-I-Husayn Yahyá al-Jazrayi, bajo el poder del rey Ibn Hud, señor de Murcia y enemigo del de Valencia. Según su obra, el Diwan, parece que fue el gobernador el que le había animado a abandonar el reino de Aragón y trasladarse a Xàtiva. Este le ayuda económicamente y, sobre todo, anímicamente, volviéndole a una situación honrosa y respetable.

Todo hace suponer que permaneció en Xàtiva hasta la muerte de su amigo el gobernador. Entonces, intenta conseguir el favor del rey de Valencia, Ibn Zayyân Mardânish, justificando sus servicios con Abu Zayd y el gobernador de Xàtiva. Le dedica una casida en la que menciona la proclamación de la soberanía califal abbasí y sus colores heráldicos. ${ }^{10}$ También influyó en el acercamiento el hecho de que pertenecían los dos a familias nobles de Onda, que siempre habían tenido una gran amistad, siendo colaboradores en la época almohade. Además,

9 «Permitió mi mala suerte que me encontrase con una banda, que se llevo mi dinero, para empeorar mi situación», pág. 42 de la traducción del Diwan de Santiago Martínez de Fco.

10 Diwan, pág. 359-360, según Dr. Djomaa Chekha. 
tenían los dos sentimientos comunes hacia la religión y el amor a su tierra.

Fue cadí de Dénia y Valencia, reemplazando a su maestro Abu-Sulayman Ibn-Haut-Allah. El rey Zayyân Mardânish le nombra su visir, que es un cargo equivalente al de primer ministro, ayudante o valido de un monarca.

Las tropas de Jaime I empiezan el asedio de Valencia en el ramadán del 635 de la hégira (abril de 1238). El rey Zayyân envía a Ibn Al-Abbâr al frente de una embajada a pedir ayuda a Abú Zakariyya, emir de Túnez. Allí recitó su famosa Salvad al-Ándalus (casida en sin, el Diwan, núm. 185), en la que describe las trágicas circunstancias en que se encontraba la ciudad de Valencia, la destrucción de los sitios religiosos además, narra enfurecidamente a sus enemigos de ojos azules (de malagüero para los árabes), «donde ya se oyen las campanas en vez del canto del muecín». El emir decide ayudarlos enviando armas, dinero y víveres por medio de doce naves, pero no tropas.

Al llegar a Valencia el 12 de agosto, ven cortado el acceso al puerto por la armada aragonesa, por lo que deciden ir a Dénia. Cuando Ibn al-Abbâr llega a Valencia, sus habitantes ya se disponen a rendirse, tras cinco meses de asedio, a las tropas de Jaume el Barcelonés (Jacomu Al-Barxaluni, así lo llama en sus escritos).

Algunos historiadores dicen que fue un fracaso el resultado del viaje a Túnez, ya que no tuvo el efecto que se esperaba, sobre todo el más importante, el apoyo militar. Esto le puso en evidencia ante el emir de Valencia y, poco a poco, fue perdiendo su influencia en la corte. De hecho, no estuvo en el sequito de Zayyân en su exilio.

Zayyân Mardânish le elige como mediador en las negociaciones de rendición y el 29 de septiembre de 1238 Ibn al-Abbâr firma el acta de capitulación a la corona de Aragón. ${ }^{11}$ Entre los acuerdos está que tenían veinte días para salir de Valencia todos los que quisieran marcharse libremente, con sus

11 El pergamino 74 de Jaime I, en el Archivo de la Corona de Aragón, no lleva firma alguna, por lo que debe de ser algún borrador, ya que lo lógico sería que el documento estuviera en bilingüe y firmado por los monarcas y testigos, entre ellos Ibn Al-Abbar.

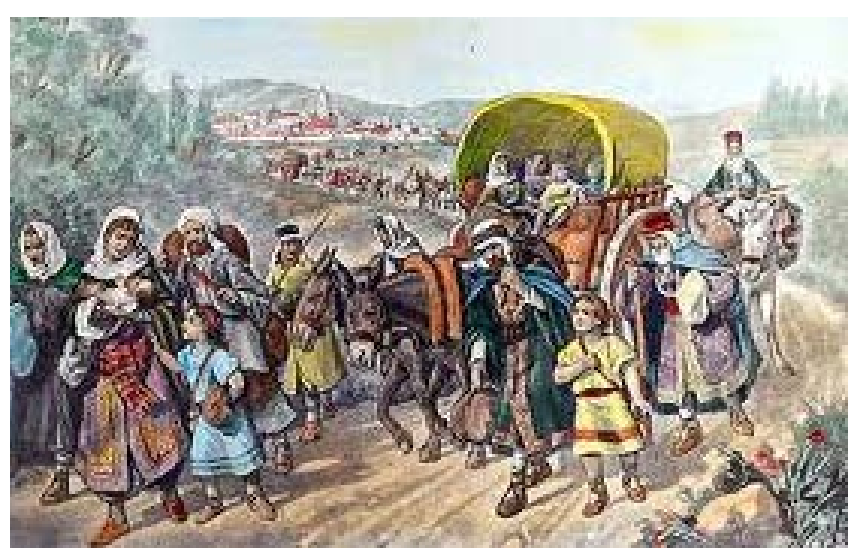

Figura 4

familias, armas y enseres, siempre al sur del Júcar. Los que se quedaran estarían bajo protección real y debían de entenderse con sus nuevos señores. Jaime I concede una tregua de siete años a Zayyân y le cede lo que pidió: las plazas de Cullera y Dénia. A cambio, este le otorga las tierras que le seguían siendo fieles, entre ellas el castillo de Onda, cuya rendición es resultado del pacto de capitulación.

Las clases dirigentes (nobles, políticos, intelectuales, religiosos, etc.), incluidos el propio Zayyân y su secretario, parten hacia las tierras cedidas al sur del Júcar y otros al norte de África. Posteriormente, el mismo rey gobierna en Murcia (Xàtiva, Dénia, Cartagena, Lorca y Vera) y busca acuerdos con Castilla, bien para conservar su territorio o buscar aliados para reconquistar Valencia. También se pone bajo el reinado de Abú Zakariyya, emir de Túnez, para buscar apoyos. En 1245 fue derrocado.

La mayoría del pueblo llano permaneció en sus casas y aldeas. Simplemente era cambiar de señores que les cobraban los impuestos, por ello no les compensaba a arriesgarse un exilio incierto.

Nuestro personaje, de nuevo, hace un viaje en diciembre de 1239 a Túnez contactando con Abú Zakariyya, para pedir de nuevo ayuda militar, como recoge en su casida Socorre al-Ándalus (núm. 1) de su Diwan, tan desgarradora como la primera, ${ }^{12}$ sin ningún resultado. Regresa a Mursiyya (Murcia) en 1240, donde gobierna Za-yyân Mardânish. Poco después viajará con su familia nuevamente

12 Termina el poema «Qué tremendo que la gente del infierno haya ocupado un paraíso existente que extiende sobre ello sus sombras», pág. 64 de la traducción del Diwan, de Santiago Martinez de Fco. 


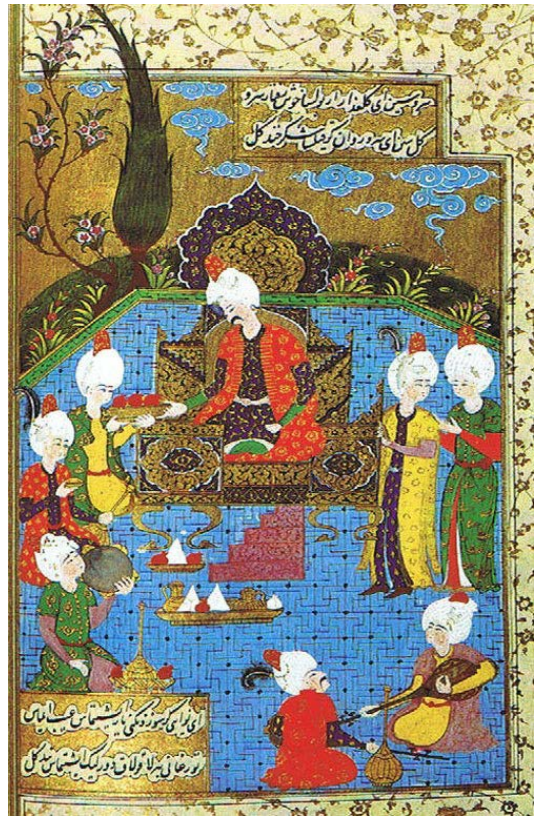

Figura 5

a Túnez, donde permanecerá más de veinte años, hasta su muerte. No olvida Al-Ándalus, pues ahora están también acosadas Sevilla y Córdoba, la antigua capital Omeya. Él se lo recordará al soberano tunecino constantemente.

En Túnez gobernaba la dinastía de los hafsíes, recientemente instaurada. Eran hombres de caracteres fuertes y desconfiados. El Califa Abú Zakariyya no envía refuerzos para la reconquista ante su insistencia. Lo instala en su cancillería; quiere un buen escribano como Al-Abbâr para redactar cartas en prosa rimada y que componga casidas en su honor. Pero este, que había sido visir o primer ministro, no se resigna a ser un simple secretario como en su juventud y le reprocha al soberano el que no vaya a ayudar a sus hermanos de fe.

Por su actitud crítica hacia el emir, en 1248 es desterrado a Burgia, donde se dedica a escribir. Ya no es indignación política o religiosa lo que siente, sino rabia por estar desterrado, exiliado en una edad madura, y se da cuenta de que ha perdido la ju-ventud y su querida patria. Siempre escribe sobre la nostalgia hacia su Sharq Al-Ándalus y del tiempo pasado.

Los historiadores posteriores tienden a describir a nuestro autor como orgulloso y antipático, señalando que solía irritar al emir con su erudición y sus elogios a Al-Ándalus. Un ejemplo de su prepotencia es que, cuando Abú Zakariyya le nombra jefe de la cancillería, le dio orden de dejar un espacio en blanco en la parte superior de todos los documentos oficiales, para que su ministro AbuI-Abbas al-Gassani tuviera sitio para poner el emblema, el nombre del príncipe y la firma. No acató la orden y, cuando se le insistió, estalló de rabia, rompió la pluma y recitó un verso de autoelogio de al-Mutanabbí. Se consideraba de una etnia superior, era árabe puro (al Qudâ 'i) y sus señores Hafsíes berberiscos. Es muy probable que su carácter se hubiera degradado desde que se exiliara, al perder amigos y paisajes. Por otra parte, la emigración andalusí había ido a parar mayoritariamente a Bugía y Túnez, en cuya administración se colocaron muchos de ellos, lo que provocó la hostilidad de los tunecinos.

Abû Zakariyyâ le llama a la corte y le indulta, pero muere poco después y le sucede al-Mustansír, hijo del anterior visir. Monarca desalmado, hubo varias revueltas populares durante su mandato. Ibn alAbbâr pasa a ser su consejero.

Ibn al-Abbâr es nombrado secretario de firma y jefe de cancillería. Considerado habilidoso político y competente administrativo, su formación y experiencia eran muy superiores que las del resto de los cortesanos, creando envidia y pugna entre ellos, como el ministro Abu-I-Husayn y el encargado del sello califal Ibrahim al-Gassani.

No se sabe por qué, quizás por las intrigas de los cortesanos y su carácter, en 1252 al-Mustansir le destierra a Bugía, como hiciera su padre antes, y allí escribe nuevamente dos obras, una de ellas actualmente desaparecida. Al extinguirse definitivamente el califato de Bagdad en 1258, al-Mustansir se proclamó califa y las mismas Medina y La Meca le dieron su reconocimiento.

En 1259 recibe el perdón del monarca y es llamado a la corte. El califa lo restituyó en el cargo, ya que era el más capaz y experimentado en asuntos políticos de toda la corte, pero a la vez al-Mustansir tenía miedo a que le fuera infiel y a su soberbia. Un año más tarde, sus enemigos intrigaron contra él. En la corte le denominaban el rata.

Se desconoce la causa exacta por la que fue condenado, pero se barajan varias. Una era la pugna entre andalusíes y tunecinos. Los primeros se con- 
sideraban superiores y orgullosos, eran ilustrados, médicos, poetas, científicos, etc., vivían separados de los tunecinos, que eran comerciantes, agricultores y de otros oficios.

Otro motivo fue que realizó un horóscopo al príncipe heredero al-Wâthiq, que auguraba la caída del reino, lo que era causa suficiente de condena política. Además, se le acusó de chiita, es decir, enemigo de los suníes, argumento seguramente falso aunque algunos autores lo apoyan y que también es motivo suficiente para condenarlo. Igualmente que hablaba y escribía mal del visir, además se le acusó de estar en una conspiración para derrocarlo. Algunos autores aún amplían más los motivos de su condena, pero creo que fue una suma de todo. El califa ordenó un registro en su casa, donde hallaron verso que decía: «En Túnez reina un tirano al que neciamente llaman califa...».

Ibn al-Abbâr murió alanceado el 6 de enero de 1260, y su cadáver y sus libros fueron quemados. Este hecho demuestra que la razón de su muerte estaba más allá del miedo al individuo: era también a su influencia social y política. El califa nunca confió plenamente en él, pues tenía miedo a la pérdida de su reino, ya que era una dinastía de reciente creación. No quería gente que no le apoyara fielmente, y más aún con la arrogancia y carácter de Al-Abbâr.

\section{Ibn al-Abbâr, el escritor}

El profesor Abd as-Sallam Al.Harràs, decano de la Facultad de Letras en Fez, una de las mayores autoridades de literatura andalusí, afirma que ${ }^{13}$

Ibn Al-Abbâr de València és potser el primer escriptor responsable en la història d'Al Ándalus fins mitjan del segle vir de l'Hègira, potser fins el final; i qui millor va reflexar en la seua poesía la problemàtica i la preocupació del seu país.

Se calcula que escribió unos cuarenta y cinco libros, de diferentes ramas, de los cuales solo han llegado completos hasta nosotros seis y restos de otros. Se centran en cuatro ejes fundamentales: historia, biografía, ensayista y poesía. Solo con estas pocas

13 Huguet i Pacual, Jesús (1999). Ibn Al-Abbar: Memòria a recordar. Butlletí d'estudis Municipal, 2. ${ }^{a}$ etapa- Núm. 1, Onda. obras y las referencias de otros autores sobre él, es suficiente, según los expertos, para considerarlo uno de los grandes intelectuales musulmanes del siglo XIII.

Ha sido resaltado como uno de los iniciadores entre los musulmanes del estudio crítico de la historia. Es un punto de referencia en obras sobre la historia del Magreb y Al-Ándalus, escribe sobre los almorávides y los almohades, así como de las conquistas cristianas de su época. Algunos especialistas dicen que su nombre puede figurar al lado de Ibn Hayyàn, máximo historiador del Al-Ándalus.

Su producción biográfica lo sitúa entre los grandes biógrafos árabes de todos los tiempos. Estas obras nos lo muestran como un infatigable recopilador de la sabiduría del mundo andalusí y musulmán en general. Persistente y original, Ibn al-Abbâr será el primer biógrafo árabe que incluirá mujeres en sus repertorios, para sorpresa y escándalo de contemporáneos y posteriores. Quizás sea este tema de biógrafo, el que más fama le ha dado.

La descripción que hace Jesús Huguet ${ }^{14}$ en Memories a recordar de la obra poética es muy elocuente:

Los poemas de Ibn al-Abbâr están muy lejos de la clásica literatura árabe del desierto y la trashumancia. Son hijos de una concepción vital derivada de una noción nítidamente mediterránea $y$, a menudo, voluptuosa. Las relaciones personales, la bebida, los manjares, la delicadeza en el vestir señalan unas maneras poco ortodoxas, una determinada idea de vivir fuertemente ligada a la efervescencia y el epicureísmo de la civilización mediterránea.

En el fondo de todas sus escrituras se encuentra su amor a lo patrio de Sharq Ándalus. Bellas residencias, fértiles huertos, flores abiertas, lecturas y sabidurías coránicas, gentes vinculadas al saber, sus orígenes, etc. Después de su exilio, aún exalta más las exquisiteces de su amada tierra y gentes. El Dr. Abd A-Salâm Al-Harrâs, en su trabajo sobre Al-Abbâr Un poeta fiel a su patria, dice:

14 Jesús Huguet Pascual (Onda, 1944) es un escritor, editor, sociolingüista y político. Actualmente es secretario ejecutivo del Consell Valencia de Cultura desde el 2002. Licenciado en derecho y filologia, es profesor de la Universitat de València y de otras internacionales. 
el poeta visir pasaría años hablando a la vez de sí mismo y de la causa de su patria. La herida era profunda y afectaba a toda la intimidad, sin esperanza de cura. Llora la pérdida de Balansiya, sigue preso de la añoranza de sus jardines, huertos, la Ruzafa, la Albufera. En la poesía utiliza diversas simbologías de los lugares donde jugó y donde pasó su niñez.

A continuación realizamos la descripción de algunas de sus obras.

\section{Históricas y biográficas}

- At-Takmila fi kitâb as-Sila, traducido como Suplemento a las adiciones biográficas. Un manuscrito se encuentra en la Biblioteca de El Escorial. Este libro es quizás el más importante y conocido; fue escrito como complemento del Kitâb al-Sila. de Ibn Baskuwal. ${ }^{15}$ Es uno de los diccionarios biográficos musulmanes más utilizado por los investigadores. Hay que destacar que hace referencia también a intelectuales femeninas, cosa muy importante dada la posición de la mujer dentro de la religión islámica. Por medio de esta obra, también se asiste al avance de los cristianos por el Al-Ándalus, a la emigración de los ulemas de sus tierras, lo que hace de la Takmila una crónica histórica de esa época.

- Mu'yam fî ashâb Abû 'Alî as-Safadi, en castellano Diccionario de discípulos de Abû 'Alî asSadafi, contiene 350 biografías de sabios de Al-Ándalus.

- Kitâb al Hulla al Siyara (La túnica recamada), es una colección de biografías de personalidades y orígenes de diversas familias del Magreb (norte de África) y Al-Ándalus. La obra está compuesta con la intención de ser, además, una antología poética, dedicada especialmente a los poemas compuestos por príncipes e intelectuales de estas tierras en la Takmila, donde trata de acumular la mayor cantidad posible de biografías. En Al Hulla, hace un criterio selectivo: autores de obras poéticas de calidad y que pertenecen a las grandes y nobles familias del islam. El autor habla del entorno familiar y los orígenes del personaje, lo que hace que sea

15 Ávila Navarro, María Luisa. Ibn Hárit, fuente De Ibn AlAbbár. Escuela de Estudios Árabes, c S I c , Granada. una biografía dentro de la biografía. En este libro redacta las negociaciones y la firma de la entrega de Valencia, en la que estuvo presente.

- I'tâb al-kuttâb (Restitución de secretarios), libro histórico y biográfico, escribe sobre los funcionarios que sufrieron la represión de sus sultanes y califas. En su introducción pide perdón al califa de Túnez que le restituye en el cargo.

\section{Obra poética}

- Qita'-ar-riyàd (Recogido en el parque), antología poética de Ibn Al-Abbár. Según algunos expertos, es de un altísimo sentido estético y claramente un testimonio para considerarlo un maestro entre los clásicos de la literatura árabe.

- Diwan ${ }^{16}$ (palabra de origen persa, que significa: reunió). Son poesías y escritos variados, entre ellos se encuentra la famosa casida que recita ante el rey de Túnez sobre la situación de Balansiya ante Jaume el Barcelonés: «Veniu cap a València amb els vostres genets...». No se ha podido recuperar totalmente. Un manuscrito se encuentra en la Biblioteca Real de Marruecos.

El Dr. Cheikha, catedrático de literatura de la Universidad de Túnez, en su trabajo El valor documental del Diwân de Ibn Añl-Abbâr, dice:

nos muestra que estamos ante un autor de una extensa cultura, que abarca muchas áreas de conocimiento y al que no le tiembla la pluma, teniendo además las ocupaciones políticas e intelec-tuales, siendo uno de los más grandes poetas del norte de Áfiqiya y del Al-Ándalus del s. XIII.

El Diwan tiene dos partes: una de su vida en SharqÁndalus y la otra en el destierro. Ibn Al-Abbâr va describiendo lo que sucedía a su alrededor, tanto a nivel personal como social. Narra la historia de la época, las batallas, su estancia en tierras cristianas, el posterior reproche de sus conciudadanos, y la caída de Valencia, sobre la que escribe que «está perdida, con su terror y violencia, que fue como un huracán que soplase sobre las almas y las dejase profiriendo ayees de dolor y sufrimiento».

16 Publicado por el Dr. Abb as-Sallâm Al-Harras (1985). Casa tunecina de Ediciones. Túnez. 
Sharq-Andalus era para el poeta el jardín del paraíso. Después de la conquista cristiana, pasa a ser terreno de contradicciones, de lugar de agua a sedienta, de morada del amor al odio, de la civilización a barbará.

En su viaje hacia el exilio, con el dolor de la separación de su tierra amada, las molestias del viaje, con una familia numerosa y su equipaje, él padece por los sufrimientos de sus hijos. Son temas que va desgranando en sus escritos. También en su estancia en Túnez escribe sobre la familia Hafsi, cantando su glorias y cualidades. Posteriormente, cae en desgracia varias veces, de las cuales también comenta en sus escritos, cambiando su aprecio hacia la dinastía reinante.

\section{Como ensayista}

- Durar as-simt fi jabar as-sibt. (La sarta de perlas: noticias sobre la casta del Profeta o las cuentas del collar de la historia del nieto del Profeta). Se conservan cinco manuscritos, uno en la Biblioteca Nacional de Madrid. Habla de su propio linaje, que es el del profeta Mahoma. También del primo y yerno de este, Alí, y de su hija Fátima, y de los descendientes de estos. Del enfrentamiento entre chiítas y sunnitas, ${ }^{17}$ las dos tendencias religiosas más importantes del islam.

Escrito en prosa rimada, como es el estilo del Corán. Abundan las rimas externas e internas, hipérboles y metáforas. ${ }^{18}$ Describe a los descendientes del Profeta como los astros del buen camino, datileras o un árbol bendito; a Alí y sus descendientes en metáforas como águila o halcón, aves nobles y significativas del bien en la cultura musulmana. Argumenta la legitimidad de los chiitas, como ejemplo hablando de Fátima (hija de Mahoma y esposa de Alí): «Ese es el favor de Dios, que Él da a quien quiere. El árbol bendito no tiene otra rama que ella, mas

17 Los sunnitas u ortodoxos (sunna=tradición), seguidores de los primeros califas y sucesores del Profeta; los chiitas, partidarios de Alí, yerno de Mahoma. Las dos tendencias reclamaban su legitimidad.

18 Algunos autores ven la influencia de la poesía andalusí en la Generación del 27 (http://eprints.ucm.es/9431/1/ T30906.pdf Poesía del 27)

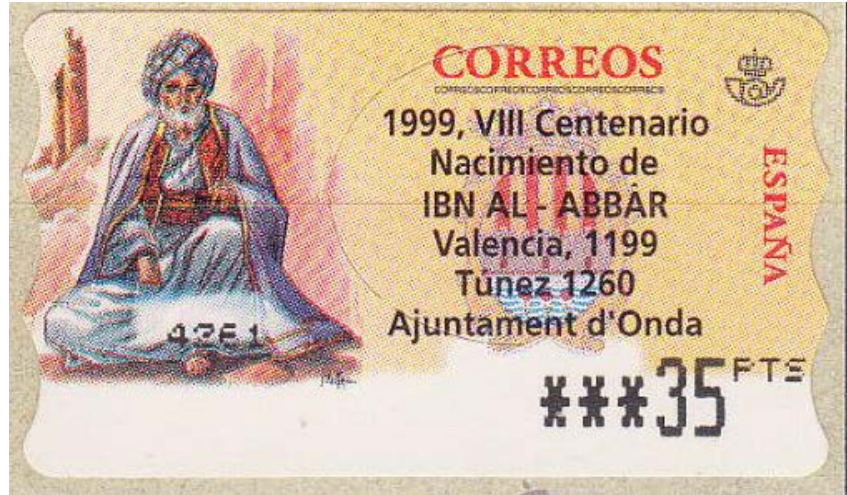

Figura 6. Sello conmemorativo del viII centenario del nacimiento de Ibn Al Abbâr

¿hay fruto más copioso que el de esta rama?». Por este libro se le acusa como partidario del chiismo frente al dogma sunita.

Este argumento también fue uno de los motivos de su condena. En el fondo, solo quería criticar a los omeyas, ya que manifestaba que la ortodoxia de estos desvirtuaba el mensaje del Profeta. Aunque algunos autores como Santiago Martínez de Francisco ${ }^{19}$ abogan por su evolución verdadera hacia el chiismo.

- Tuhfat al-qâdim (Regalo del que llega), crítica sobre la literatura andalusí y biografía de sus poetas.

- Ma'adin al-luyain fi maràtì al Husayn (Filón de plata), estudio sobre las elegías dedicadas a Husayn.

- Hidâya al-mu'tarif fi-l-mu'talif wa-I-mujtalif (Guía provechosa para el inquieto en la armonía y la disensión).

Otras obras: El Vendaval. Recuerdos de la patria amada. El verde brocado. El guiño al relámpago. En torno a los poetas de Oriente. En torno a los poetas de Al-Ándalus.

El epitafio a Al Mu'tamid (rey de Sevilla y poeta) fue unos versos de nuestro escritor: «Se ganó el amor y la compasión de las gentes: aún hoy le lloran».

19 Traductor de varios libros de Ibn Al-Abbar en su libro La epopeya de los Alíes, pág. XIV argumenta que el poeta se pudo convertir al chiismo en Bugía o incluso en Sahrq AlAndalus. 


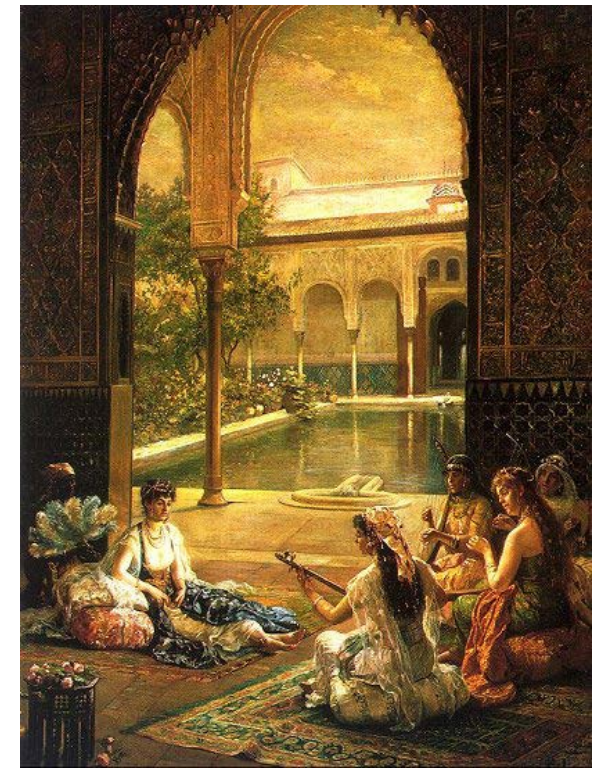

Figura 7

Adjunto una serie de casidas de su Diwan ${ }^{20}$ que me parecen significativas.

\subsection{Poesías de temas variados}

\section{La noria}

¡Oh Dios! ¡Qué bella es la noria que gira como una esfera celeste, aunque no haya en ella ningún lucero!

La colocaron sobre el río unas manos que decretaron, que regocijara a las almas mientras trabajaba penosamente.

Parece un hombre libre encadenado, o mejor, un prisionero que marcha libremente.

Como el agua sube en ella para luego bajar, parece la nube que toma su provisión de los mares y luego la derrama.

Los ojos la aman porque el jardín es su comensal,

y ella como un copero que no bebe.

\section{Espectáculo circense (núm. 39) sobre la vejez}

Cuidado, la juventud ya pasó, confórmate con tus canas.

¿Cómo ofreces a los ojos hermosos

$\mathrm{y}$ anhelas la hermosa boca?

La pasión en la vejez

es culpa grave: jarrepiéntete!

Tras agotarse la savia juvenil

y secarse la fértil madurez...

20 De la traducción de Santiago Martínez de Francisco. Véase la bibliografía.

\section{Amor de juventud (núm. 100)}

Frescura de la vista, mis ojos te desean y no descansan si no es con tu visión. Por Dios, mi mirada sólo anhela tu claridad y el aroma que exhalas...

\subsection{Poesía en sus destierros}

\section{Nostalgia de Valencia (núm.183)}

Cada vez que hablan de Levante, gimo como una tórtola, y cada vez que brilla el relámpago, lloro como las nubes. La lluvia envidia las lágrimas que derramo, y la tórtola mis gemidos por mi tierra.

\section{Recuerdo de la Ruzafa ${ }^{21}$ (núm.194)}

¡Que hermosos días los de la Ruzafa, que representan el esplendor de la mocedad! Mas han dejado tal ardor en mi corazón que si no lo regase con mi llanto, se habría derretido en sus llamas. ¿Cómo añoran mis pupilas los jardines a cuyos estanques corren los arroyos, como madres que van a sus niños a echarles la comida que llevan bajo su camisa!

\section{En tierras cristianas ${ }^{22}$ (núm.9)}

Han dicho: Emigrar a tierras cristianas es una falta,

Y yo digo: En absoluto, más bien es un mérito.

Salí por lealtad, luego volví por devoción, y elogiaron mi acto enemigos y amigos.

En Quraysh tengo un ejemplo, y es suficiente que los sagaces se entendieran con el Negús.

Casidas dedicadas a los mandatarios de varios reinos:

- Zayyân Mardânish (Diwan núm. 168): «Luchas defendiendo la recta religión como tu padre Mudafi en la guerra y resistes firme...».

- Salvad al-Ándalus (casida en sin, núm. 185) y Socorre al-Ándalus (núm. 1): A los Hafsíes

21 Ruzafa es el nombre de una finca de las afueras de Valencia, homónima de la que tuvo el califa Abd Rahman I en las afueras de Córdoba.

22 Justifica su marcha como secretario del rey Abu Zayd a Zaragoza, luego hace hincapié en su estirpe y hace mención que en tiempos del Profeta algunos se refugiaron en el reino cristiano de Abisinia. 
(reyes de Túnez) depende de las épocas igual los alaba como los demoniza (casida núm. 178) «No sabían que estoy bajo la protección de un califa, en cuya diestra están la muerte y el sustento... ${ }^{23}$ En Túnez oprime un tirano al que necia-mente llaman califa».

- También les exalta (núm. 120): «La muerte se llevo al defensor del Islam. Su estrella llamó a la sustitución de su estancia en la tierra por aquella del Paraíso...».

Algunas obras de Ibn-Al-Abbâr han sido musicadas por el grupo Capella de Ministrers, ${ }^{24}$ como su poesía La senía. ${ }^{25}$

\subsection{Poesía erótica}

\section{La cita nocturna}

Recatándose medrosa de la gente que la espía, con andar tácito y ágil llegó mi prenda querida.

Su hermosura por adorno en vez de joyas lucía. $\mathrm{Al}$ ofrecerle yo un vaso y darle la bienvenida, el vino en su fresca boca se puso rojo de envidia.

Con el beber y el reír cayó en mi poder rendida. por almohada amorosa le presenté mi mejilla,

y ella me dijo: «en tus brazos dormir anhelo tranquila»

Durante su dulce sueño a robar mil besos iba; mas ¿quién sacia el apetito robando su propia finca?

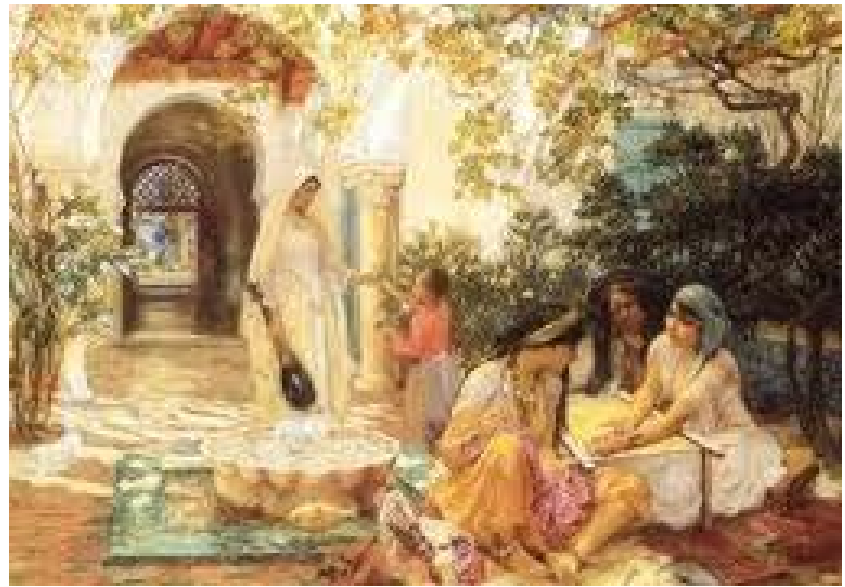

Figura 8

Mientras esta bella luna sobre mi pecho yacía, se oscureció la otra luna, que los cielos iluminan.

Pasmada dijo la noche: «¿Quién su resplandor me quita?»

¡Ignoraba que en mis brazos la luna estaba dormida!

23 Prerrogativas que en el islam solo las tiene Dios.

24 Capella de Ministrers es un grupo de música valenciano, fundado en 1987 por su director Carles Mangraner. Interpretan música vocal e instrumental, especializados en la interpretación del patrimonio musical español, con criterios fieles a la época e instrumentos históricos.

25 http://www.capelladeministrers.es/index.asp?pagina=di scos\&c $=25 \&$ subpagina $=8680$

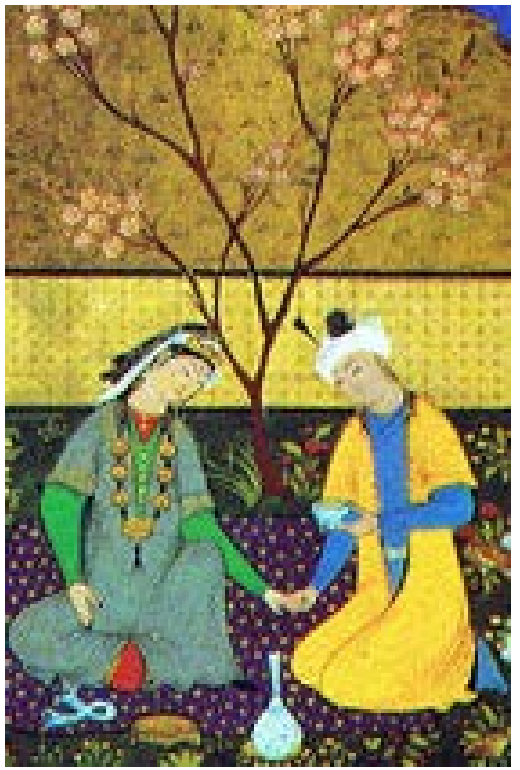

Figura 9 


\section{Referencias}

Ardit, Manuel (1993). Els homes i la terra del País Velenciá (segles XVI-XVIII). Biblioteca d’Historia del Països Catalans. Curial. Barcelona.

Cerda, Manuel (dir) (1988). Historia del Pueblo Valenciano. Graficuatre.

Codera y Zaidin, Francisco (1886). Biblioheca Arabico-hispana, tomo IV. Boletín de la Real Academia de la Historia. http://bib.cervantesvirtual.com/servlet/SirveObras/01371852122385963092257/p0000023.htm\#I_38_21/07/2013

- (1887). Biblioheca Arabico-hispana, tomo V. Boletín de la Real Academia de la Historia. http://bib.cervantesvirtual. com/servlet/SirveObras/12615095346702617432435/p0000032.htm\#I_45_21/07/2013

Garcia Edo, Vicent (1989). Butlletí d’estudis Onders. Miralcamp.

De Epalza, Mikel y Huguet Jesus (1989). Ibn Al-abbar, Polític i escriptor àrab valencià. Conselleria de Cultura. Generalitat Valenciana.

Huguet i Pacual, Jesús (1999). Ibn Al-Abbar: Memòria a recordar. Butlletí d’estudis Municipal 2. etapa, núm. 1, Onda.

Lachica, Margarita (2008). Poetas árabes del Pais Valenciano. Anales de la Universidad de Alicante. Historia Medieval, 9, 17-37.

Martínez de Francisco, Santiago (2003). Ibn Al-Abbar, Salva Al-Andalus y otros poemas. Traducción de El Diwan por Abd as-Salam Al-Harras, Huerca-Fierro editores. Túnez 1985.

- (1990). La epopeya de los Alíes. Traducción de La sarta de perlas de Ibn Al-Abbar, por Abd as-Salam Al-Harras y Sa’id Ahmad A’rab. Tetuán 1972, Miraguano Editores. Madrid

Molin, Luis (1990). La Takmila de Ibn- Al-Abbâr, fuente para la historia del siglo viII, en Ibn-alAbbar polític i escriptor àrab valencia (1119-1260) coord. Mike de Epalza. Consejo Superior de Investigaciones Científicas. Escuela de Estudios Árabes, Generalitat Valenciana. http://digital.csic.es/bitstream/10261/17195/1/Molina_La\%20Takmila.pdf $21 / 07 / 2013$

Moral, Celia (2009). Jardines y fuentes en al-Andalus a través de la poesía. Miscelánea de estudios árabes y hebraicos. 58, 223-248 http://www.cabei.es/pdf/revistas/5.pdf 21/07/2013

Prats, Jaime (2002). La Valencia de Ibn-Abbar. http://www.elpais.com/articulo/Comunidad/Valenciana/Valencia/ Ibn/al-Abbar/elpepiautval/20020420elpval_26/Tes 21/07/2013

Rull Villar, Baltasar. (1967). Noticiario histórico de Onda, Graficas Magovi. 